\title{
Erratum to: Flavonoids as Multi-Target Inhibitors for Proteins Associated with Ebola Virus: In Silico Discovery Using Virtual Screening and Molecular Docking Studies
}

\author{
Utkarsh Raj $^{1}$ - Pritish Kumar Varadwaj ${ }^{1}$
}

Published online: 18 September 2015

(c) International Association of Scientists in the Interdisciplinary Areas and Springer-Verlag Berlin Heidelberg 2015

\section{Erratum to: Interdiscip Sci Comput Life Sci DOI 10.1007/s12539-015-0109-8}

Unfortunately in the original article, the references 3, 5, 7 and 9 were published incorrectly. The correct references are published in this erratum. They are as given below.

(3) Dixon MP, Pau RN, Howlett GJ, Dunstan DE, Sawyer WH, Davidson BE (2002) The central domain of Escherichia coli TyrR is responsible for hexamerization associated with tyrosine-mediated repression of gene expression. J Biol Chem 277(26):23186-23192

(5) Hartlieb B, Modrof J, Mühlberger E, Klenk HD, Becker S (2003) Oligomerization of Ebola virus VP30 is essential for viral transcription and can be inhibited by a synthetic peptide. J Biol Chem 278(43):41830-41836

(7) Hartlieb B, Muziol T, Weissenhorn W, Becker S (2007) Crystal structure of the C-terminal domain of Ebola virus VP30 reveals a role in transcription and nucleocapsid association. Proc Natl Acad Sci USA 104(2):624-629. Epub 3 Jan 2007

(9) Weik M, Modrof J, Klenk HD, Becker S, Mühlberger E (2002) Ebola virus VP30-mediated transcription is regulated by RNA secondary structure formation. J Virol 76(17):8532-8539
The online version of the original article can be found under doi: 10.1007/s12539-015-0109-8.

\section{Utkarsh Raj}

utkarsh.iiita@gmail.com

1 Bioinformatics Division, Indian Institute of Information Technology, Allahabad, India 